\title{
Dexamethasone enhances SOX9 expression in chondrocytes
}

\author{
I Sekiya, P Koopman ${ }^{1}$, K Tsuji, S Mertin ${ }^{2}$, V Harley ${ }^{2}$, Y Yamada ${ }^{3}$, \\ K Shinomiya ${ }^{4}$, A Nifuji and M Noda
}

\author{
Department of Molecular Pharmacology, Tokyo Medical and Dental University, Tokyo, Japan \\ ${ }^{1}$ Center for Molecular and Cellular Biology, University of Queensland, Brisbane, Australia \\ ${ }^{2}$ Howard Florey Institute of Experimental Physiology and Medicine, University of Melbourne, Parkville, Victoria, Australia \\ ${ }^{3}$ Laboratory of Developmental Biology, National Institutes of Dental and Craniofacial Research, Bethesda, Maryland, USA \\ ${ }^{4}$ Department of Orthopaedic Surgery, Tokyo Medical and Dental University, Tokyo, Japan \\ (Requests for offprints should be addressed to M Noda, Department of Molecular Pharmacology, Medical Research Institute, Tokyo Medical and Dental \\ University, 2-3-10 Kanda-Surugadai, Chiyoda-ku, Tokyo, 101, Japan; Email: noda.mph@mri.tmd.ac.jp)
}

\begin{abstract}
SOX9 is a transcription factor that activates type II procollagen (Col2a1) gene expression during chondrocyte differentiation. Glucocorticoids are also known to promote chondrocyte differentiation via unknown molecular mechanisms. We therefore investigated the effects of a synthetic glucocorticoid, dexamethasone (DEX), on Sox9 gene expression in chondrocytes prepared from rib cartilage of newborn mice. Sox9 mRNA was expressed at high levels in these chondrocytes. Treatment with DEX enhanced Sox 9 mRNA expression within $24 \mathrm{~h}$ and this effect was observed at least up to $48 \mathrm{~h}$. The effect of DEX was dose dependent, starting at $0 \cdot 1 \mathrm{nM}$ and maximal at $10 \mathrm{nM}$. The half life of Sox9 mRNA was approximately
\end{abstract}

$45 \mathrm{~min}$ in the presence or absence of DEX. Western blot analysis revealed that DEX also enhanced the levels of SOX9 protein expression. Treatment with DEX enhanced Col2a1 mRNA expression in these chondrocytes and furthermore, DEX enhanced the activity of Col2-CAT (chloramphenicol acetyltransferase) construct containing a $1.6 \mathrm{~kb}$ intron fragment where chondrocytespecific Sry/Sox-consensus sequence is located. The enhancing effect of DEX was specific to SOX9, as DEX did not alter the levels of Sox6 mRNA expression. These data suggest that DEX promotes chondrocyte differentiation through enhancement of SOX9.

Journal of Endocrinology (2001) 169, 573-579

\section{Introduction}

Sox9 is a member of the family of Sox (Sry-type HMG box) genes which were first identified on the basis of a region with a high homology to Sry (Sex-determining region Y) (Gubbay et al. 1990, Wright et al. 1993). This region encodes a 79 amino acid motif known as the HMG box, which is responsible for sequence-specific DNA binding. Several HMG box proteins are known to act as transcription factors (Giese et al. 1992, Harley et al. 1994) and some of the Sox genes have been shown to be expressed in a tissue-specific manner during development (reviewed by Wegner 1999). Sox9 is expressed predominantly in mesenchymal condensations throughout the embryo in the regions where deposition of cartilage matrix is taking place, suggesting a role in skeletal formation (Wright et al. 1995, Ng et al. 1997, Zhao et al. 1997). In addition, mutations in human SOX9 result in campomelic dysplasia, characterized by skeletal malformation and XY sex reversal (Foster et al. 1994, Wagner et al. 1994). In mouse chimeras, Sox9-/- cells are excluded from all cartilaginous tissues during embryonic development but are present in juxtaposed mesenchyme that does not express chondrocyte-specific markers such as procollagen type II, IX, XI and aggrecan (Bi et al. 1999). SOX9 regulates expression of the gene encoding type II procollagen (Col2a1), the major matrix protein characteristic of chondrocytes. SOX9 protein binds to the specific sequences in the first intron of Col2a1 gene and activates Col2a1 gene expression in vitro (Lefebvre et al. 1997) and in vivo (Bell et al. 1997). In addition, we showed that SOX9 enhanced aggrecan gene promoter/enhancer activity in a cartilage-derived cell line (Sekiya et al. 2000). These observations indicate that Sox9 plays a key role in chondrogenesis and skeletogenesis.

Glucocorticoids have been demonstrated to promote differentiation of chondrocytes and to maintain the integrity of the cartilaginous matrix in isolated primary cell populations (Jones \& Addison 1975, Kato \& Gospodarowicz 1985, Takano et al. 1985, Horton et al. 1987, Quarto et al. 1992) as well as in chondrogenic cell lines (Calcagno et al. 1970, Grigoriadis et al. 1988, 1989). In addition, glucocorticoids suppress cartilage phenotype expression in vitro and in vivo depending on culture 
conditions (Tessler \& Salmon 1975, Silbermann \& Maor 1985).

In this study we examined whether the effects of glucocorticoids on chondrocyte differentiation might be mediated by modulation of Sox 9 gene expression in chondrocytes.

\section{Materials and Methods}

\section{Cell culture}

Our experiments were conducted in accordance with the guidelines of the animal care committee of Tokyo Medical and Dental University. Chondrocytes were prepared from rib cartilage of 0- to 7-day-old ICR mice (Lefebvre et al. 1994). Rib cages were incubated in 680 units $/ \mathrm{ml}$ collagenase (Sigma, St Louis, MO, USA) in DMEM (Gibco BRL, Rockville, NY, USA) for $30 \mathrm{~min}$ at $37^{\circ} \mathrm{C}$, rinsed with PBS and then incubated in 680 units $/ \mathrm{ml}$ collagenase in DMEM at $37^{\circ} \mathrm{C}$ in a $\mathrm{CO}_{2}$ incubator for $3 \mathrm{~h}$. Undigested bony parts were discarded, and primary chondrocytes were plated at $10^{5} \mathrm{cells} / \mathrm{cm}^{2}$ in tissue culture plastic dishes and subjected to experiments within several days. Standard culture medium consisted of DMEM supplemented with antibiotics (100 units $/ \mathrm{ml}$ penicillin G sodium, $100 \mu \mathrm{g} / \mathrm{ml}$ streptomycin sulfate and $0 \cdot 25 \mu \mathrm{g} / \mathrm{ml}$ amphotericin B) and 10\% FBS (Gibco BRL). Dexamethasone (DEX) (Sigma) was dissolved in 95\% ethanol and DEX solutions $\left(10^{-2}, 10^{-3}, 10^{-4}, 10^{-5}\right.$ and $\left.10^{-6} \mathrm{M}\right)$ were prepared. All cultures including control received an equivalent amount of ethanol at 0.0095\%.

\section{Northern blotting}

We used a $1.6 \mathrm{~kb}$ EcoRI-BglII fragment of the mouse Sox9 cDNA (Wright et al. 1995), a 0.4 kb EcoRI-Hind III fragment of the mouse Col2a1 cDNA (Metsaranta et al. 1991), and a $0.5 \mathrm{~kb}$ XhoI-BamHI fragment of the mouse Sox6 cDNA as a probe (Connor et al. 1995). A $1 \cdot 2 \mathrm{~kb}$ EcoRI fragment of the glyceraldehyde-3-phosphate dehydrogenase (GAPDH) probe was used as a control.

Total cellular RNA was prepared according to the acid guanidium thiocyanate-phenol-chloroform method (Chomczynski \& Sacchi 1987). Aliquots of $10 \mu \mathrm{g}$ of the total RNA per lane were electrophoresed in $1.0 \%$ agarose gels containing $0.66 \mathrm{M}$ formaldehyde and transferred to nylon filters (Hybond-N, Amersham Pharmacia Biotech, Piscataway, USA) by electroblotting. Filters were incubated at $42{ }^{\circ} \mathrm{C}$ for $1 \mathrm{~h}$ in a hybridization buffer $(50 \%$ formamide, $250 \mathrm{mM}$ sodium phosphate $\mathrm{pH} 7 \cdot 2,25 \mathrm{mM}$ sodium chloride, $0.5 \%$ sodium dodecylsulfate (SDS), $0.2 \mathrm{mg} / \mathrm{ml}$ herring sperm DNA, 10\% polyethylglycol MW 6000, $10 \times$ Denhardt's solution (0.4\% Ficoll type 400, $0 \cdot 4 \%$ polyvinyl-pyrolidone, $0 \cdot 4 \%$ BSA fraction V)). Each cDNA was labeled using the BcaBEST random primer labeling kit (Takara Shuzo Co., Ltd, Tokyo, Japan) and $\alpha-{ }^{32} \mathrm{P}-\mathrm{dCTP}$ (NEN Life Science Products, Boston, MA, USA). Hybridization was performed at $42^{\circ} \mathrm{C}$ for $24 \mathrm{~h}$ in a fresh hybridization buffer containing $1 \times 10^{6}$ c.p.m./ml of the labeled probe.

Filters were washed in $2 \times \mathrm{SSC}, 0 \cdot 5 \%$ SDS for $20 \mathrm{~min}$ at room temperature and in $0.2 \times \mathrm{SSC}, 0.5 \%$ SDS for $20 \mathrm{~min}$ at $65^{\circ} \mathrm{C}$. Filters were exposed to X-ray film using intensifying screens at $-80^{\circ} \mathrm{C}$. The bands in the northern blot autoradiographs were quantified by densitometry and each value was normalized against that of the GAPDH band in the corresponding lane. The normalized values obtained were used to calculate fold induction.

\section{Western blotting}

Twenty-four hours after DEX treatment, approximately 6 million chondrocytes per dish were scraped in a lysis buffer $(150 \mathrm{mM} \mathrm{NaCl}, 1 \mathrm{mM}$ phenylmethylsulfonyl fluoride (PMSF), $1 \%$ Triton $\times 100,1 \times$ protease inhibitor Complete (Boehringer Mannheim, Indianapolis, IN, USA), 20 mM Tris pH 8.0) (Murakami et al. 2000a,b). Approximately $2 \cdot 6 \mathrm{mg}$ protein per dish was obtained and $40 \mu \mathrm{g}$ protein per lane was used for Western blotting. The supernatants were used for Western blotting. Extracts were fractionated on 10\% SDS-polyacrylamide gel and transferred to Immobilon-P membrane (Millipore, Molsheim, France). The filters were blocked in 5\% skim milk in Tris-buffered saline overnight and incubated with a 1/5000 dilution of SOX9 antibody and then incubated with a $1 / 4000$ dilution of horseradish peroxidaseconjugated goat anti-rabbit antibody. The SOX9 protein was detected by using ECL kit (Amersham Pharmacia Biotech). SOX9 antibody was produced in a rabbit which was injected with a chemically synthesized peptide coupled to KLH (keyhole limpet hemocyanin). This peptide corresponds to the amino acid sequence 486 to 509 at the C-terminus of human SOX9 protein. Hemagglutinin (HA)-tagged full length SOX9 protein was used as a positive control and luciferase protein was used as a negative control. For the production of full-length human SOX9, PBS-HA-SOX9 plasmid was constructed by PCR amplification using SOX9 cDNA as a template (Mertin et al. 1999). SOX9 protein (509 amino acids) was produced using the TNT T3-coupled rabbit reticulocyte lysate system (Promega, Madison, WI, USA).

\section{Chloramphenicol acetyltransferase (CAT) assay}

CAT assay was performed as described previously (Gorman et al. 1982). Primary chondrocytes were plated in six-well cluster plates ( $35 \mathrm{~mm}$ well diameter) at $6-7 \times 10^{4}$ cells $/ \mathrm{cm}^{2}$. One day later, these cells were transfected with pCII4-C CAT (Col2-CAT) (Horton et al. 1987) reporter construct in the absence or presence of $100 \mathrm{nM}$ DEX. Transfection was performed by using FuGENE6 
(Boehringer Mannheim). The cells were harvested $60 \mathrm{~h}$ after transfection. Cell extracts were prepared and used for the analysis of CAT activity. Protein concentrations in the cell lysates were determined according to the Coomassie Brilliant Blue G method (Spector 1978). Equivalent amounts of the cellular proteins were incubated for $2 \mathrm{~h}$ at $37^{\circ} \mathrm{C}$ in a reaction buffer $(0.25 \mathrm{M}$ Tris $-\mathrm{HCl}, \mathrm{pH} 7 \cdot 5$, $40 \mathrm{mM}$ acetyl CoA (Sigma), $\left[{ }^{14} \mathrm{C}\right]$ chloramphenicol (Amersham Corp.)). The levels of acetylation were estimated by TLC followed by autoradiography of the TLC plates. Quantitation of the acetylation levels was performed by using a Bioimaging Analyzer BAS 2000 system (Fuji Film Inc., Tokyo, Japan). The effect of Sox9 promoter activity was estimated by measuring the conversion rate. Experiments were repeated two times in triplicate with independent preparations of cell extracts. To monitor transfection efficiency, CAT activity was normalized against luciferase (LUC) activity of pGL2-control LUC-construct cotransfected with the reporter plasmids and SOX9 expression plasmid in a part of the experiments. Such experiments gave similar results to those where CAT activity was normalized against total protein contents.

\section{Statistical analysis}

For Northern blot assay, relative Sox9 expression levels were calculated as ratios of Sox 9 mRNA levels normalized against those of GAPDH. These ratios were compared between DEX-treated and control cells. Statistical evaluations were conducted by using one-sample $t$-test. $P$ values less than 0.05 were considered to be statistically significant.

For CAT assay, statistical evaluations of the data were conducted by using unpaired Student's $t$-test. Data are presented as mean \pm standard deviation (s.D.) $P$ values less than 0.05 were considered to be statistically significant.

\section{Results}

\section{DEX enhances Sox9 mRNA expression}

Sox 9 mRNA is expressed at high levels as a $4.7 \mathrm{~kb}$ band in primary cultures of chondrocytes (Fig. 1). This expression was further enhanced in the presence of DEX. The enhancement was observed within $24 \mathrm{~h}$ and lasted at least up to $48 \mathrm{~h}$ (Fig. 1). DEX enhanced Sox 9 mRNA levels in a dose-dependent manner from $0 \cdot 1 \mathrm{nM}$, with a maximum at $10 \mathrm{nM}$ (Fig. 2a,b).

To examine if DEX affects the stability of Sox9 mRNA, primary cultures of chondrocytes were first incubated for $48 \mathrm{~h}$ in the absence $(-)$ or presence $(+)$ of $100 \mathrm{nM}$ DEX, after which DRB, an inhibitor of RNA polymerase II, was added to the cultures and the stability of Sox9 mRNA was examined. Sox 9 mRNA half life was

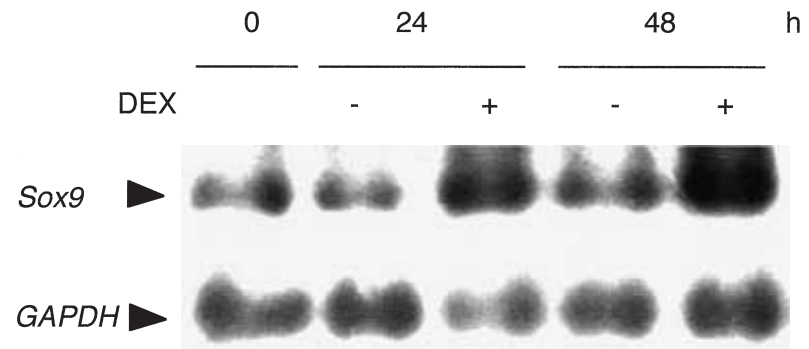

Figure 1 Time course of DEX on Sox9 mRNA expression in chondrocytes. Primary cultures of chondrocytes were treated for the indicated hours in the absence $(-)$ or presence $(+)$ of $100 \mathrm{nM}$ DEX. Total RNA was extracted and subjected to Northern blot analysis as described under Materials and Methods. Experiments were repeated three times, and representative data are shown. The enhancing effect of DEX on Sox9 mRNA levels normalized against those of GAPDH at the time point of $48 \mathrm{~h}$ was statistically significant $(P<0 \cdot 05)$.

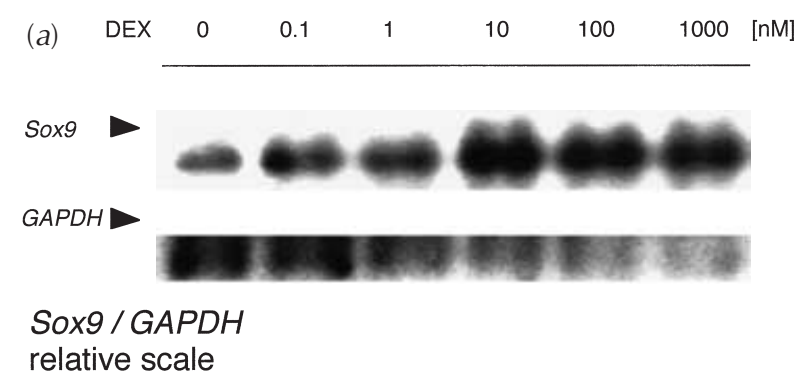

(b)

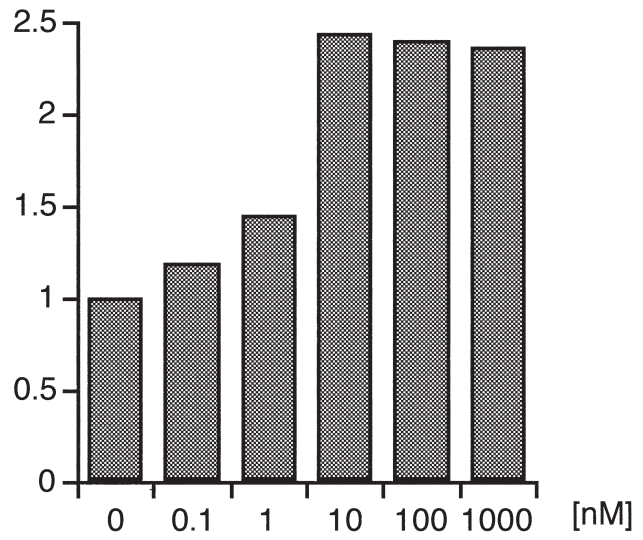

Figure 2 Dose effect of DEX on Sox9 mRNA expression in chondrocytes. Primary cultures of chondrocytes were treated with the indicated doses of DEX for $48 \mathrm{~h}$. Total RNA was extracted and subjected to Northern blot analysis as described under Materials and Methods. (a) Dose dependence of DEX effects on Sox9 mRNA expression. (b) Quantification of the data shown in (a). Data are expressed as fold induction normalized against GAPDH mRNA expression. The figure indicates the data of one of two independent experiments with similar results.

approximately $45 \mathrm{~min}$ in both the presence and absence of DEX (Fig. $3 a, b$ ), indicating that DEX does not affect the stability of Sox 9 mRNA. 


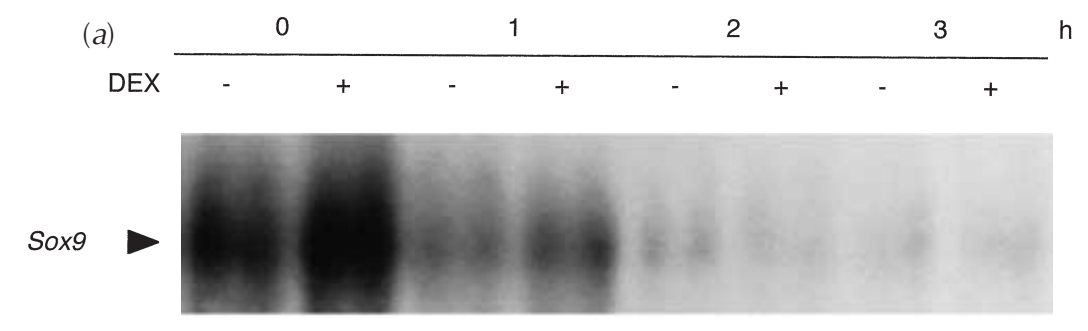

GAPDH

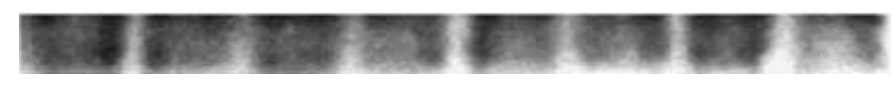

\section{Sox9 / GAPDH relative scale}

(b)

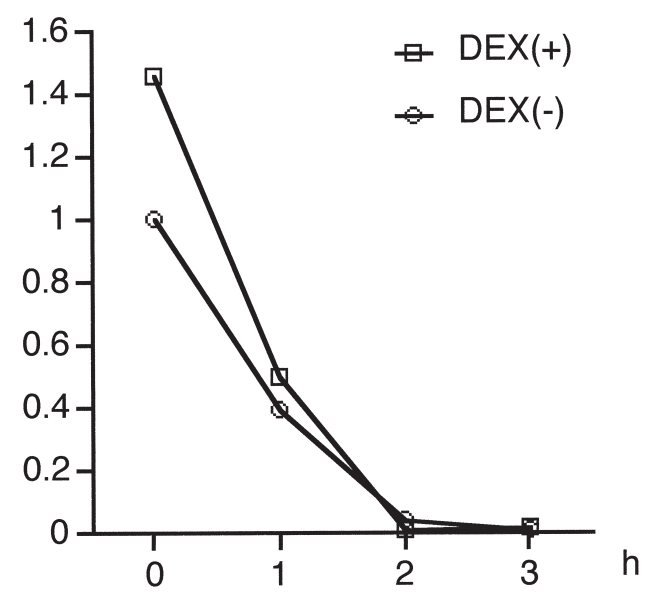

Figure 3 Stability of Sox9 mRNA enhanced by DEX treatment. (a) After primary cultures of chondrocytes were treated for $48 \mathrm{~h}$ in the absence (-) or presence (+) of $100 \mathrm{nM}$ DEX; DRB $(25 \mu \mathrm{g} / \mathrm{ml})$ was added to inhibit RNA synthesis (time 0$)$. Total RNA was extracted at 0 , 1, 2 or $3 \mathrm{~h}$ thereafter, and subjected to Northern blot analysis as described under Materials and Methods. (b) Quantitative data indicated by fold induction normalized against GAPDH mRNA expression. Experiments were repeated twice, and representative data are shown.

\section{DEX enhances SOX9 protein expression}

In order to determine whether the enhancing effect of DEX on Sox9 mRNA levels is translated into protein levels, Western blot analysis was conducted. Primary cultures of chondrocytes expressed SOX9 protein, which was detected as a $69 \mathrm{kDa}$ band. DEX enhanced the levels of SOX9 protein expression by about 50\% (Fig. 4), indicating that the effect of DEX on Sox 9 mRNA levels is translated into increased protein levels.

\section{DEX enhances transcription of the Col2a1 gene}

As DEX enhanced SOX9 expression in primary cultures of chondrocytes and SOX9 is known to enhance Col2a1 gene expression (Bell et al. 1997, Lefebvre et al. 1997), we examined whether DEX enhances transcriptional activity of Col2a1 in primary cultures of chondrocytes prepared from rib cartilage of newborn mouse (Lefebvre et al. 1994). DEX at 10 and $100 \mathrm{nM}$ has previously been reported to enhance endogenous Col2a1 mRNA expression in these cells within 48 h (Kato \& Gospodarowicz 1985) (Fig. 5a). We then examined whether DEX enhanced transcriptional activity of a Col2a1 gene fragment containing chondrocyte-specific Sry/Sox-consensus sequences. For this purpose, we used pCII4-C CAT (Col2-CAT) reporter construct that harbors a $1.6 \mathrm{~kb}$ intron fragment of murine Col2a1 gene (Horton et al. 1987). DEX at $100 \mathrm{nM}$ enhanced transcriptional activity of this CAT construct by about $50 \%$ (Fig. 5b). DEX did not alter the activity of pSV2-CAT, indicating the specificity of its effect on the Col2a1 gene fragment (Fig. 5b). 


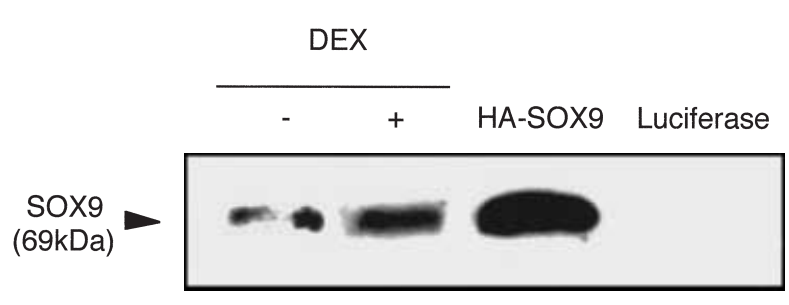

Figure 4 DEX effect on SOX9 protein expression. Primary cultures of chondrocytes were treated for $24 \mathrm{~h}$ in the absence $(-)$ or presence (+) of $100 \mathrm{nM}$ DEX. Cell extract was prepared and was subjected to Western blot analysis under Materials and Methods. HA-tagged full length SOX9 protein that migrated as a $69 \mathrm{kDa}$ band was used as a positive control and luciferase protein was used as a negative control. Experiments were repeated twice, and representative data are shown.

(a) DEX 0

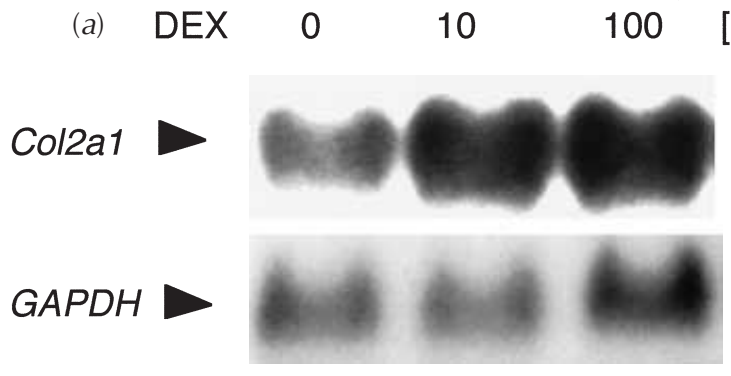

(b) DEX

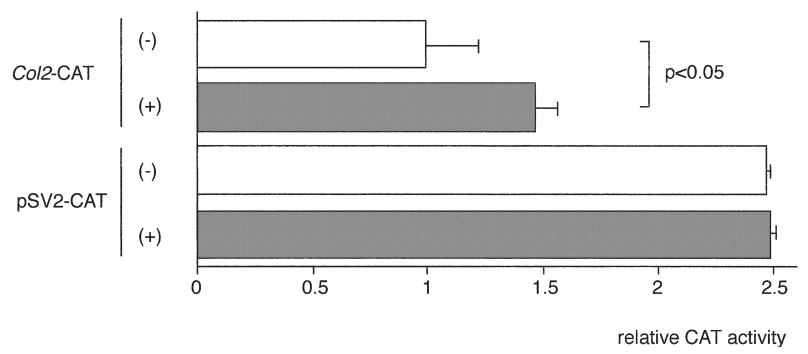

Figure 5 DEX enhancement of transcriptional activity of Col2a1 gene in chondrocytes. (a) Primary cultures of chondrocytes were treated with the indicated doses of DEX for $48 \mathrm{~h}$. Total RNA was extracted and subjected to Northern blot analysis as described under Materials and Methods. Experiments were repeated three times, and representative data are shown. (b) DEX effect on the transcriptional activity of the pCII4-C CAT (Col2-CAT) reporter construct containing chondrocyte-specific Sry/Sox-consensus sequence within the enhancer region of Col2a1 gene was examined. Primary cultures of chondrocytes were transfected with $1 \mu \mathrm{g}$ of reporter plasmid and were cultured in the absence or presence of 100 nM DEX for 60 h. pSV2-CAT plasmid was used as a positive control. CAT activity was determined as described in Materials and Methods. Experiments were repeated twice in triplicate with independent preparations of cell extracts. The representative data are shown. Data are expressed as means \pm S.D. $(n=3)$.

\section{DEX does not enhance Sox 6 mRA expression}

Another SOX protein, SOX6, is co-expressed with SOX9 during chondrogenesis and cooperates with SOX9 in

\section{DEX}

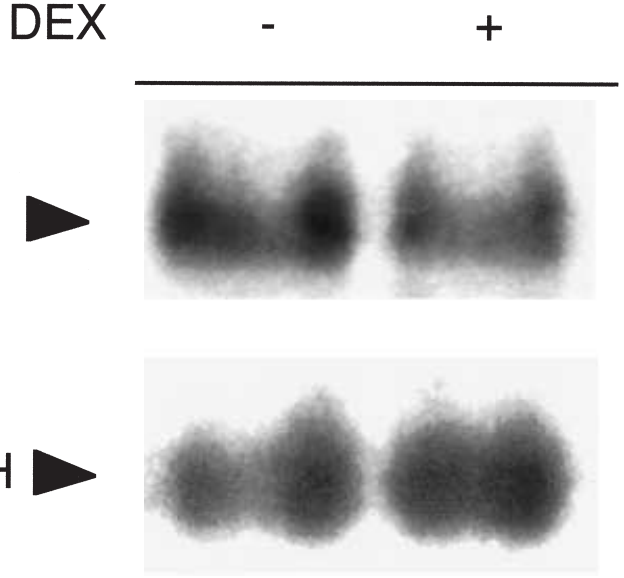

\section{GAPDH}

Figure 6 DEX effect of Sox6 mRNA expression. Primary cultures of chondrocytes were treated with $100 \mathrm{nM}$ DEX for $48 \mathrm{~h}$. Total RNA was extracted and subjected to Northern blot analysis as described in Materials and Methods. Experiments were repeated three times, and representative data are shown. The difference between Sox6 mRNA levels normalized against those of GAPDH in DEX-treated cultures and those in control cells was not statistically significant $(P=0 \cdot 20)$.

activating Col2a1 (Lefebvre \& Crombrugghe 1998). To test whether enhancement by DEX is specific to Sox9, we examined the effect of DEX on Sox6 expression in rib primary chondrocytes. In Northern blots, Sox6 mRNA expression was observed as an $8 \mathrm{~kb}$ band for these cells. DEX at $100 \mathrm{nM}$ did not alter the levels of Sox 6 mRNA expression (Fig. 6). These results indicate that the effect of DEX is specific to SOX9.

\section{Discussion}

Chondrocytes produce a unique extracellular matrix composed of proteins such as type II collagen, aggrecan and link protein. Although DEX has been shown to enhance expression of these genes (Calcagno et al. 1970, Jones \& Addison 1975, Kato \& Gospodarowicz 1985, Takano et al. 1985, Horton et al. 1987, Grigoriadis et al. 1988, 1989, Quarto et al. 1992), the molecular mechanism(s) by which DEX exerts its effects has not been elucidated. Our data indicate that DEX enhances expression of Sox9, which encodes a transcription factor known to regulate expression of genes encoding major chondrocyte-related extracellular matrix proteins, such as Col2a1, aggrecan and CD-RAP (Lefebvre et al. 1997).

The physiological relevance of the action of glucocorticoids on chondrocytes is well established. Kato \& Gospodarowicz (1985) showed that glucocorticoids promote formation of cartilage-like tissues both morphologically and biochemically in cultures of isolated 
chondrocytes. It was also reported by McCumbee and co-workers (McCumbee \& Lebovitz 1980, McCumbee et al. 1980) that glucocorticoid together with growth hormone $(\mathrm{GH})$ stimulated growth of Swarm rat chondrosarcoma implanted in hypophysectomized. In addition, Quarto et al. (1992) indicated that DEX supported chondrocyte viability. Our observation that DEX enhances Sox9 expression in chondrocytes also shows that dexamethasone acts as a positive factor for the maintenance of chondrogenic cells. However, Kato \& Gospodarowicz (1985) indicated that glucocorticoids are not required in cartilage explant system. Thus our observations on the DEX effect on SOX9 could be dependent on the cellular context that could vary according to the culture conditions such as monolayer cultures.

We showed that DEX enhanced Sox9 mRNA expression in a dose-dependent manner. Its effect was first observed at $0 \cdot 1 \mathrm{nM}$ and maximal at $10 \mathrm{nM}$. Takano et al. (1985) reported a biphasic effect of hydrocortisone on the incorporation of ${ }^{35} \mathrm{~S}$-sulfate into glycosaminoglycan in confluent cultures of rabbit costal chondrocytes, where the enhancing effect was maximal at $100 \mathrm{nM}$ and less at higher concentrations. Grigoriadis et al. (1989) also reported a dose-dependent DEX enhancement in the number of cartilage nodules formed in RCJ 3.1C5 cells, with a biphasic response with the peak at $10 \mathrm{nM}$. Although our data did not reveal biphasic action, these studies and ours are similar in that glucocorticoids enhance expression of the cartilage phenotype in a dose-dependent manner.

DEX enhanced Sox 9 mRNA and SOX9 protein expression within $24 \mathrm{~h}$, and this DEX enhancement of Sox9 mRNA expression was observed at least up to $48 \mathrm{~h}$. Recently, Murakami et al. (2000a) reported that FGF2 enhanced Sox9 mRNA expression in primary cultures of chondrocytes as early as $30 \mathrm{~min}$ after addition of FGF2 and that this increase lasted at least up to $24 \mathrm{~h}$. It is still to be determined whether DEX enhances SOX9 expression directly or indirectly through the enhancement of intermediary factors in chondrocytes.

DEX enhanced the transcriptional activity of a Col2CAT construct that contains a Sry/Sox-consensus sequences from the first intron fragment of the Col2a1 gene. However, the 50\% increase in Col2-CAT activity was not as high as the enhancement of endogenous Col2a1 mRNA expression. This suggests the existence of additional pathways by which DEX enhances Col2a1 gene expression, presumably through other sites outside the $1.6 \mathrm{~kb}$ first intron fragment.

In conclusion, we show here that SOX9 is a target of DEX regulation of chondrocyte differentiation. Whether glucocorticoid regulation of SOX9 plays a major role in regulating the chondrogenic cells as a master transcription factor requires further elucidation of downstream events following SOX9 expression.

\section{Acknowledgements}

We thank Prof. Kohtaro Furuya, Prof. Takeshi Muneta, Dr Shunichi Murakami and Dr Yoichi Ezura in the Department of Orthopaedic Surgery, Tokyo Medical and Dental University, and Prof. Haruyasu Yamamoto in the Department of Orthopaedic Surgery, Ehime University for their continuous support for this research.

This research was supported by the grants-in-aid received from the Japanese Ministry of Education (12557123, 12026212, 12215040, 0930734) grants from CREST (Core Research for Evolutional Science and Technology) of Japan Science and Technology Corporation (JST), a grant from the 'Research for the Future' Program of the Japan Society for the Promotion of Science (JSPS) (96100205), Grants from Inamori Foundation, Tokyo Biochemical Research Foundation and NASDA, to MN. PK is an Australian Senior Research Fellow of the Australian Research Council.

\section{References}

Bell DM, Leung KK, Wheatley SC, Ng LJ, Zhou S, Ling KW, Sham MH, Koopman P, Tam PPL \& Cheah KSE 1997 SOX9 directly regulates the type-II collagen gene. Nature Genetics 16 174-178.

Bi W, Deng JM, Zhang Z, Behringer RR \& de Crombrugghe B 1999 Sox 9 is required for cartilage formation. Nature Genetics 22 85-89.

Calcagno M, Goyena H, Arrambide E \& Arruti de Urse C 1970 Action of cortisone and cortisol upon biosynthesis of chondroitin sulfate in femur in vitro cultures of chick embryo. Experimental Cell Research 63 131-137.

Chomczynski P \& Sacchi N 1987 Single-step method of RNA isolation by acid guanidinium thiocyanate-phenol-chloroform extraction. Analytical Biochemistry 162 156-159.

Connor F, Wright E, Denny P, Koopman P \& Ashworth A 1995 The Sry-related HMG box-containing gene Sox6 is expressed in the adult testis and developing nervous system of the mouse. Nucleic Acids Research 23 3365-3372.

Foster JW, Dominguez-Steglich MA, Guioli S, Kwok G, Weller PA, Stevanovic M, Weissenbach J, Mansour S, Young ID \& Goodfellow PN 1994 Campomelic dysplasia and autosomal sex reversal caused by mutations in an SRY-related gene. Nature 372 525-530.

Giese K, Cox J \& Grosschedl R 1992 The HMG domain of lymphoid enhancer factor 1 bends DNA and facilitates assembly of functional nucleoprotein structures. Cell 69 185-195.

Gorman CM, Moffat LF \& Howard BH 1982 Recombinant genomes which express chloramphenicol acetyltransferase in mammalian cells. Molecular and Cellular Biology 2 1044-1051.

Grigoriadis AE, Heersche JN \& Aubin JE 1988 Differentiation of muscle, fat, cartilage, and bone from progenitor cells present in a bone-derived clonal cell population: effect of dexamethasone. Journal of Cell Biology 106 2139-2151.

Grigoriadis AE, Aubin JE \& Heersche JN 1989 Effects of dexamethasone and vitamin D3 on cartilage differentiation in a clonal chondrogenic cell population. Endocrinology 125 2103-2110.

Gubbay J, Collignon J, Koopman P, Capel B, Economou A, Munsterberg A, Vivian N, Goodfellow P \& Lovell-Badge R 1990 A gene mapping to the sex-determining region of the mouse $\mathrm{Y}$ chromosome is a member of a novel family of embryonically expressed genes. Nature 346 245-250. 
Harley VR, Lovell-Badge R \& Goodfellow PN 1994 Definition of a consensus DNA binding site for SRY. Nucleic Acids Research 22 1500-1501.

Horton W, Miyashita T, Kohno K, Hassell JR \& Yamada Y 1987 Identification of a phenotype-specific enhancer in the first intron of the rat collagen II gene. PNAS 84 8864-8868.

Jones KL \& Addison J 1975 Pituitary fibroblast growth factor as a stimulator of growth in cultured rabbit articular chondrocytes. Endocrinology 97 359-365.

Kato Y \& Gospodarowicz D 1985 Stimulation by glucocorticoid of the synthesis of cartilage-matrix proteoglycans produced by rabbit costal chondrocytes in vitro. Journal of Biological Chemistry 260 2364-2373.

Lefebvre V \& de Crombrugghe B 1998 Toward understanding SOX9 function in chondrocyte differentiation. Matrix Biology 16 529-540.

Lefebvre V, Garofalo S, Zhou G, Metsaranta M, Vuorio E \& de Crombrugghe B 1994 Characterization of primary cultures of chondrocytes from type II collagen/beta-galactosidase transgenic mice. Matrix Biology 14 329-335.

Lefebvre V, Huang W, Harley VR, Goodfellow PN \& de Crombrugghe B 1997 SOX9 is a potent activator of the chondrocyte-specific enhancer of the pro alpha1(II) collagen gene. Molecular and Cellular Biology 17 2336-2346.

McCumbee WD \& Lebovitz HE 1980 Hormone responsiveness of a transplantable rat chondrosarcoma. I. in vitro effects of growth hormone-dependent serum factors and insulin. Endocrinology 106 905-910.

McCumbee WD, McCarty KS, Jr \& Lebovitz HE 1980 Hormone responsiveness of a transplantable rat chondrosarcoma. II. Evidence for in vivo hormone dependence. Endocrinology 106 1930-1940.

Mertin S, McDowall SG \& Harley VR 1999 The DNA-binding specificity of SOX9 and other SOX proteins. Nucleic Acids Research 27 1359-1364.

Metsaranta M, Toman D, de Crombrugghe B \& Vuorio E 1991 Specific hybridization probes for mouse type I, II, III and IX collagen mRNAs. Biochimica et Biophysica Acta 1089 241-243.

Murakami S, Kan M, McKeehan WL \& de Crombrugghe B 2000a Up-regulation of the chondrogenic Sox 9 gene by fibroblast growth factors is mediated by the mitogen-activated protein kinase pathway. PNAS 97 1113-1118.

Murakami S, Lefebvre V \& de Crombrugghe B 20006 Potent inhibition of the master chondrogenic factor Sox 9 gene by interleukin-1 and tumor necrosis factor-alpha. Journal of Biological Chemistry 275 3687-3692.

$\mathrm{Ng}$ LJ, Wheatley S, Muscat GEO, Conway-Campbell J, Bowles J, Wright E, Bell DM, Tam PPL, Cheah KSE \& Koopman P 1997
SOX9 binds DNA, activates transcription, and coexpresses with type II collagen during chondrogenesis in the mouse. Developmental Biology 183 108-121.

Quarto R, Campanile G, Cancedda R \& Dozin B 1992 Thyroid hormone, insulin, and glucocorticoids are sufficient to support chondrocyte differentiation to hypertrophy: a serum-free analysis. Journal of Cell Biology 119 989-995.

Sekiya I, Tsuji K, Koopman P, Watanabe H, Yamada Y, Shinomiya K, Nifuji A \& Noda M 2000 SOX9 enhances aggrecan gene promoter/enhancer activity and is up-regulated by retinoic acid in a cartilage-derived cell line, TC6. Journal of Biological Chemistry 275 10738-10744.

Silbermann M \& Maor G 1985 Receptor-mediated glucocorticoid inhibition of cell proliferation in mouse growth cartilage in vitro. Acta Endocrinologica 108 343-350.

Spector T 1978 Refinement of the coomassie blue method of protein quantitation. A simple and linear spectrophotometric assay for less than or equal to $0 \cdot 5$ to 50 microgram of protein. Analytical Biochemistry 86 142-146.

Takano T, Takigawa M \& Suzuki F 1985 Stimulation by glucocorticoids of the differentiated phenotype of chondrocytes and the proliferation of rabbit costal chondrocytes in culture. Journal of Biochemistry 97 1093-1100.

Tessler RH \& Salmon WD, Jr 1975 Glucocorticoid inhibition of sulfate incorporation by cartilage of normal rats. Endocrinology 96 898-902.

Wagner T, Wirth J, Meyer J, Zabel B, Held M, Zimmer J, Pasantes J, Bricarelli FD, Keutel J, Hustert E et al. 1994 Autosomal sex reversal and campomelic dysplasia are caused by mutations in and around the SRY-related gene SOX9. Cell 79 1111-1120.

Wegner M 1999 From head to toes: the multiple facets of Sox proteins. Nucleic Acids Research 27 1409-1420.

Wright EM, Snopek B \& Koopman P 1993 Seven new members of the Sox gene family expressed during mouse development. Nucleic Acids Research 21744.

Wright E, Hargrave MR, Christiansen J, Cooper L, Kun J, Evans T, Gangadharan U, Greenfield A \& Koopman P 1995 The Sry-related gene Sox 9 is expressed during chondrogenesis in mouse embryos. Nature Genetics 9 15-20.

Zhao Q, Eberspaecher H, Lefebvre V \& De Crombrugghe B 1997 Parallel expression of Sox 9 and Col2a1 in cells undergoing chondrogenesis. Developmental Dynamics 209 377-386.

Received 22 December 2000

Accepted 5 February 2001 